\title{
Measurement of Forest Above-Ground Biomass Using Active and Passive Remote Sensing at Large (Subnational to Global) Scales
}

\author{
Richard M. Lucas ${ }^{1,2}$ • Anthea L. Mitchell ${ }^{1}$ - John Armston ${ }^{2,3}$
}

Published online: 13 August 2015

(C) Springer International Publishing AG 2015

\begin{abstract}
Within the global forest area, a diverse range of forest types exist with each supporting varying amounts of biomass and allocations to different plant components. At country to continental scales, remote sensing techniques have been progressively developed to quantify the above-ground biomass (AGB) of these forests, with these based on optical, radar, and/or light detection and ranging (LiDAR) (airborne and spaceborne) data. However, none have been found to be globally applicable at high $(\leq 30 \mathrm{~m})$ resolution, largely because of different forest structures (e.g., heights, covers, allocations of AGB) and varying environmental conditions (e.g., frozen, inundated). For this reason, techniques have varied between the major forest biomes. However, when combined, these estimates provide some insight into the distribution of AGB at country to global levels with associated levels of uncertainty. Comparisons of data and derived products have, in some cases, also contributed to our understanding of changes in carbon stocks across large areas. Further improvements in estimates are anticipated with the launch of new spaceborne
\end{abstract}

This article is part of the Topical Collection on Remote Sensing

Richard M. Lucas

rml@aber.ac.uk

John Armston

john.armston@dsiti.qld.gov.au

1 Centre for Ecosystem Science, School of Biological Earth and Environmental Sciences (BEES), The University of New South Wales, High Street, Kensington, New South Wales 2052, Australia

2 Joint Remote Sensing Research Program, The University of Queensland, Brisbane, Queensland 4072, Australia

3 Remote Sensing Centre, Landscape Surface Sciences, Science Division, Department of Science, Information Technology and Innovation, GPO Box 5078, Brisbane, Queensland 4001, Australia
LiDAR and SAR that have been specifically designed for better retrieval of forest structure and AGB.

Keywords Above-ground biomass $\cdot$ Carbon $\cdot$ Remote sensing $\cdot$ Forests $\cdot$ Continental

\section{Introduction}

Approximately $30 \%$ (3869 million ha) of the world's land area is forested, with 3335 million ha covered by closed canopy forests [1]; typically with $>40 \%$ tree cover. Within this area, a diversity of forest types occur with their distribution determined largely by climate, soils, and topography [2••]. The standing above-ground biomass (AGB) of these forests constitutes about $80 \%$ of terrestrial AGB, which amounts to 432 billion Mg of dry matter, (averaging $109 \mathrm{Mg} \mathrm{ha}^{-1}$; [1]). Within the forested area, increases in AGB (carbon) occur through growth, with rates of uptake greater for forests in the early stages of regeneration but slowing asymptotically when mature [3]. Nevertheless, forests can continue to sequester carbon beyond maturity [4]. Decreases in AGB are the result of tree mortality and removal (e.g., through wildfires, windthrow, drought, inundation, logging and/or clearing). The associated release of carbon dioxide $\left(\mathrm{CO}_{2}\right)$ can be immediate (e.g., through burning) or gradual (e.g., through decomposition). The extent of losses in forest extent and biomass caused by human disturbance has been substantial and progressive, resulting in a significant contribution to overall greenhouse gas emissions (around $17 \%$; [5]). Originally covering an area of about 6.2 billion hectares (about $47 \%$ of the Earth's land surface about 8000 years ago; [6]), over $40 \%$ has been cleared with most occurring during and following the Industrial Revolution [1].

Primarily, as a consequence of the role of forests in regional to global carbon budgets, accurate measures of the spatio- 
temporal variation in the AGB of forests at country to global scales are needed. At the country level, estimates facilitate national inventory reporting, with information on carbon stocks and change used to support carbon trading and climate change initiatives such as the United Nations Framework Convention on Climate Change (UNFCCC) Reducing Emissions from Deforestation and Degradation (REDD+) program [7]. Woody vegetation AGB is often a key requirement for government land use monitoring programs and knowledge of the drivers of change in forest AGB is useful to natural resource managers when planning conservation and restoration initiatives (e.g., in degraded and regrowth forests). Global-scale AGB maps are informative and educational and provide an overview of where large-scale carbon stocks are located and can be used as a predictor of other carbon pools (e.g., below ground). However, the generation of maps across these scales remains a challenge and can be contentious [8]. This is partly because the different forest structures and environmental conditions require different approaches to AGB estimation. As a result, approaches have ranged from interpolation of field-based estimates to direct and indirect measurement using passive optical and/or active remote sensing data.

As many countries and regions are developing remote sensing methods for retrieving AGB, a review of the different methods used is informative. This review therefore focuses on AGB retrieval techniques for the major forest biomes defined by [9] (Tropical/subtropical moist broadleaf forest, dry broadleaf and coniferous forest, mangroves, tropical/subtropical and temperate grasslands, savannas, and shrublands, Mediterranean forests, woodlands and scrub; temperate broadleaved, coniferous and mixed forests, and boreal forests) with a view to establishing commonalities and differences between these. Some forest types (e.g., temperate broadleaved, mixed and coniferous forests and boreal forests) were considered together because of similarities in the architecture of trees and the structure of stands. The review emphasizes the different structures, AGB quantities, and environmental conditions within different forest biomes that have led to the different techniques being selected and applied. Only those approaches relevant to standing AGB are considered; other carbon pools (e.g., herbaceous, coarse-woody debris, below ground) are beyond the scope of this review.

\section{Characteristics of Different Forest Types}

Based on the scheme of [9], maps of 14 major biomes were generated, with eight representing forests, a further two being grasslands, savannas, and shrublands and the remainder representing deserts, shrublands and/or herbaceous vegetation (Fig. 1). This classification scheme was selected as the basis for comparing remote sensing methods as the classes reflect differences in the woody structure (closed/open forests, shrubs) as well as the foliage components of vegetation.
Between these biomes, the structural characteristics vary considerably. Using the Moderate Resolution Imaging Spectroradiometer (MODIS) Vegetation Continuous Fields (VCF) algorithm, [12••] generated a global map of percentage tree cover at 500-m spatial resolution (Fig. 2a). Forests that are contiguous over thousands of square kilometers and which supported the highest tree covers were associated with the tropical and subtropical moist broadleaved zones of South America (namely Amazonia), the Congo Basin and insular Southeast Asia, the temperate zone of the northern USA and the boreal zones (taiga) of North America and Siberia. The lowest covers were associated with the dry broadleaved forests (e.g., in India) and the tropical, subtropical, and/or temperate savanna woodlands of Central Asia, southern Africa, South America (Cerrado), the African Sahel, and Australia. Those of intermediate cover included the temperate broadleaf, coniferous and mixed forests and boreal forests of North America, Europe, and Siberia. Using Ice, Cloud, and Land Elevation Satellite (ICESat) Geoscience Laser Altimeter System (GLAS) data at a global level (Fig. 2b), [13] found that extensive and contiguous areas of tall $(>25 \mathrm{~m})$ forests were located primarily in the humid tropics and subtropics. The tallest trees and those that exhibited the greatest height variability were found in the temperate coniferous forests, while the shortest trees were located in the boreal regions. Other notable areas with tall trees included southeast and southwest Australia, the eastern Himalayas, and northeastern USA. [14] also produced a global canopy height map at $1-\mathrm{km}$ resolution using ICESat GLAS data. In comparison to [12••], canopy height estimates were generally greater. In the tropical belt, for example, estimates for closed to open broadleaf evergreen or semi-deciduous forest were, on average, $12-\mathrm{m}$ taller but were around 7-m taller in the boreal zone.

The architecture of trees also varies between biomes. In the boreal zone, for example, trees with excurrent (pine-like) growth forms predominate although these also occur in other regions (e.g., in the tropics and subtropics, [15]). Decurrent (branching) forms are, however, the most prevalent globally and are common to deciduous and/or evergreen forests in the temperate zones, Mediterranean forests and woodlands, savanna woodlands, and tropical rainforests. Palms and bamboos are also distinct in their structural formation while some trees are unique in supporting substantive prop root systems (e.g., [16]; Rhizophoraceae mangroves). The allocation of biomass to different components also varies, with [17•] noting, for example, a greater allocation to branches and leaves for broadleaved and needle-leaved trees, respectively, in boreal and temperate forests.

In many regions, environmental conditions impact on the physiology of trees and their overall structure. For example, forests inundated by freshwater for all or part of the year include the Varzea regions of the Amazon, the swamp forests of the Congo, and the peat swamp forests of Southeast Asia 


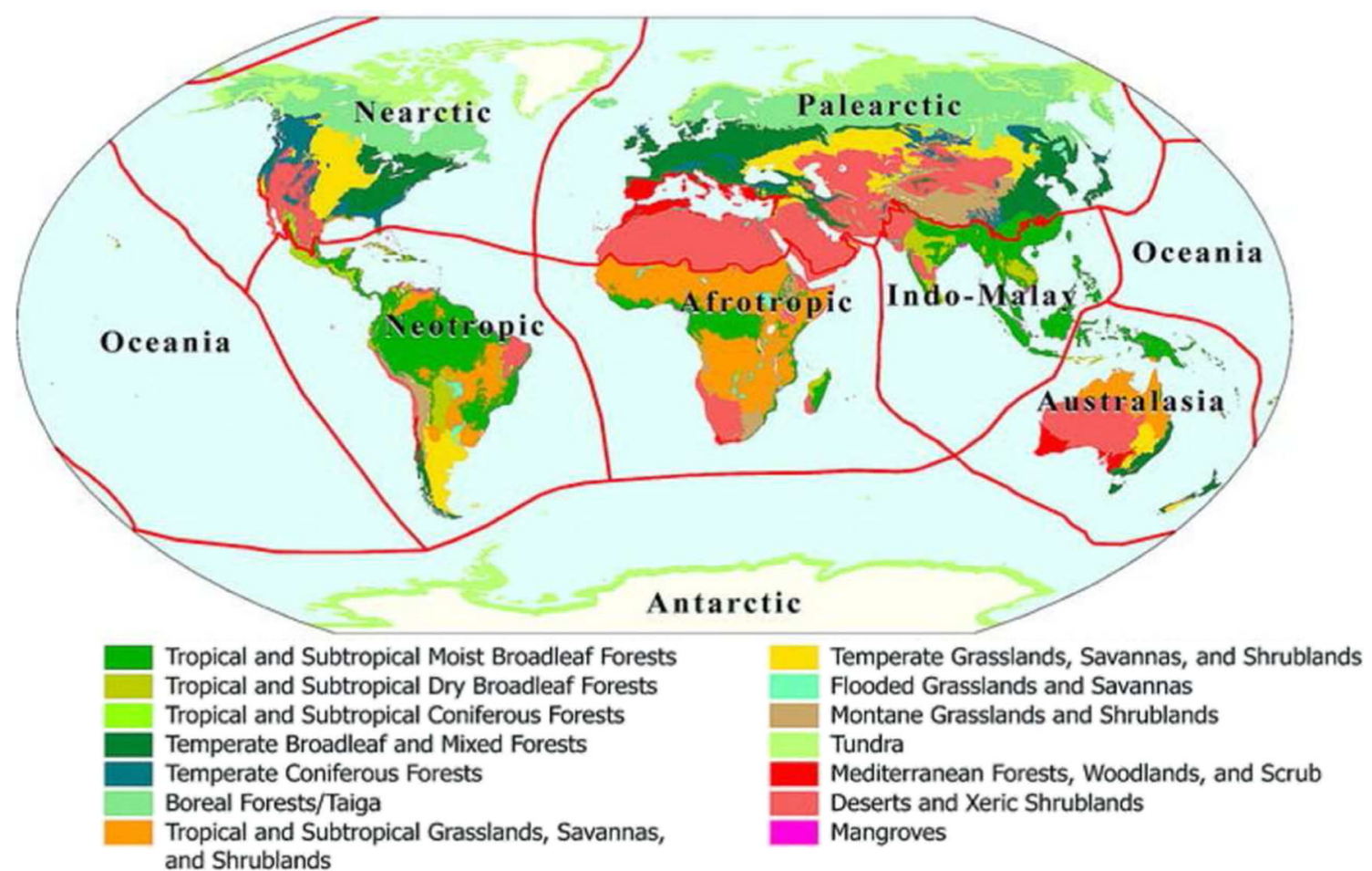

Fig. 1 Classification of biomes and ecoregions, based largely on the biogeographic realms of [9-11]

[18]. In these situations, the prevalence of water often leads to trees of lower stature [19]. However, in semi-arid areas experiencing seasonal flooding within and close to river channels, the tree height and cover can be greater compared to forests that are not able to make use of the water. Along the coastal fringes of tropical, subtropical, and some temperate regions, tidally inundated areas typically support mangrove species, with their composition and structure depending, in part, on their tolerance to salinity [20]. In the boreal regions, freeze-thaw cycles affect the functioning of plants and hence, their structural development.

The differences between forests in terms of their structure and the prevailing environmental conditions is fundamental to understanding why different studies have used different remote sensing techniques in the retrieval of biophysical attributes, including AGB. The following sections therefore review a selection of remote sensing techniques that have been applied to each of the major forested biomes and assess the uniqueness and commonalities of these.

\section{Methods by Forest Biomes}

\section{Tropical and Subtropical Moist Broadleaved Forests}

In most tropical and subtropical regions with broadleaved forests, the high AGB leads to saturation of relationships with optical data but also Synthetic Aperture Radar (SAR) acquired across the range of frequencies (namely X-, C-, L- and P- band). For this reason, other approaches have been adopted with many using data from the Geoscience Laser Altimeter System (GLAS) instrument on board the Ice, Cloud, and land Elevation (ICESat) satellite because of its ability to estimate the height of forests (which relates indirectly to AGB). As examples, $[21 \cdot, 22]$ generated maps of tropical forest AGB for the early 2000s and for 2007-2008, with both using relationships between ICESat GLAS and ground-based estimates of AGB. Extrapolation was achieved using MODIS sensor and Shuttle Radar Topographic Mission (SRTM) data, although [21•] also used QuikSCAT radar scatterometer data. In [21•], the uncertainty in AGB estimates at the 1-km pixel scale (averaged over all continents) was $\pm 30 \%$, but was not uniform across regions or AGB ranges (ranging from \pm 6 to $\pm 53 \%$ ). Regional uncertainties were comparable for Latin America ( $\pm 27 \%)$, Africa ( $\pm 32 \%)$, and Asia ( $\pm 33 \%)$. The standard deviation of errors in the MODIS-based models of [22] was estimated at 6.6, 3.6, and 3.2 \% for tropical Africa, America, and Asia, respectively, while the root mean square error (RMSE) was estimated at, respectively, 25, 19, and $24 \mathrm{Mg} \mathrm{C} \mathrm{ha}{ }^{-1}$ for these regions. Model accuracy increased where a larger number of GLAS footprints (e.g., at least 5) were within a single MODIS pixel. Substantial differences in the spatial distribution of carbon densities existed at the regional scale but aggregated country or biome scale maps were more agreeable (Fig. 3; [23]). These regional differences between maps corresponded to areas with a lack of field data.

By integrating ICESat GLAS and wall-to-wall Advanced Land Observing Satellite (ALOS) Phased Arrayed L-band 

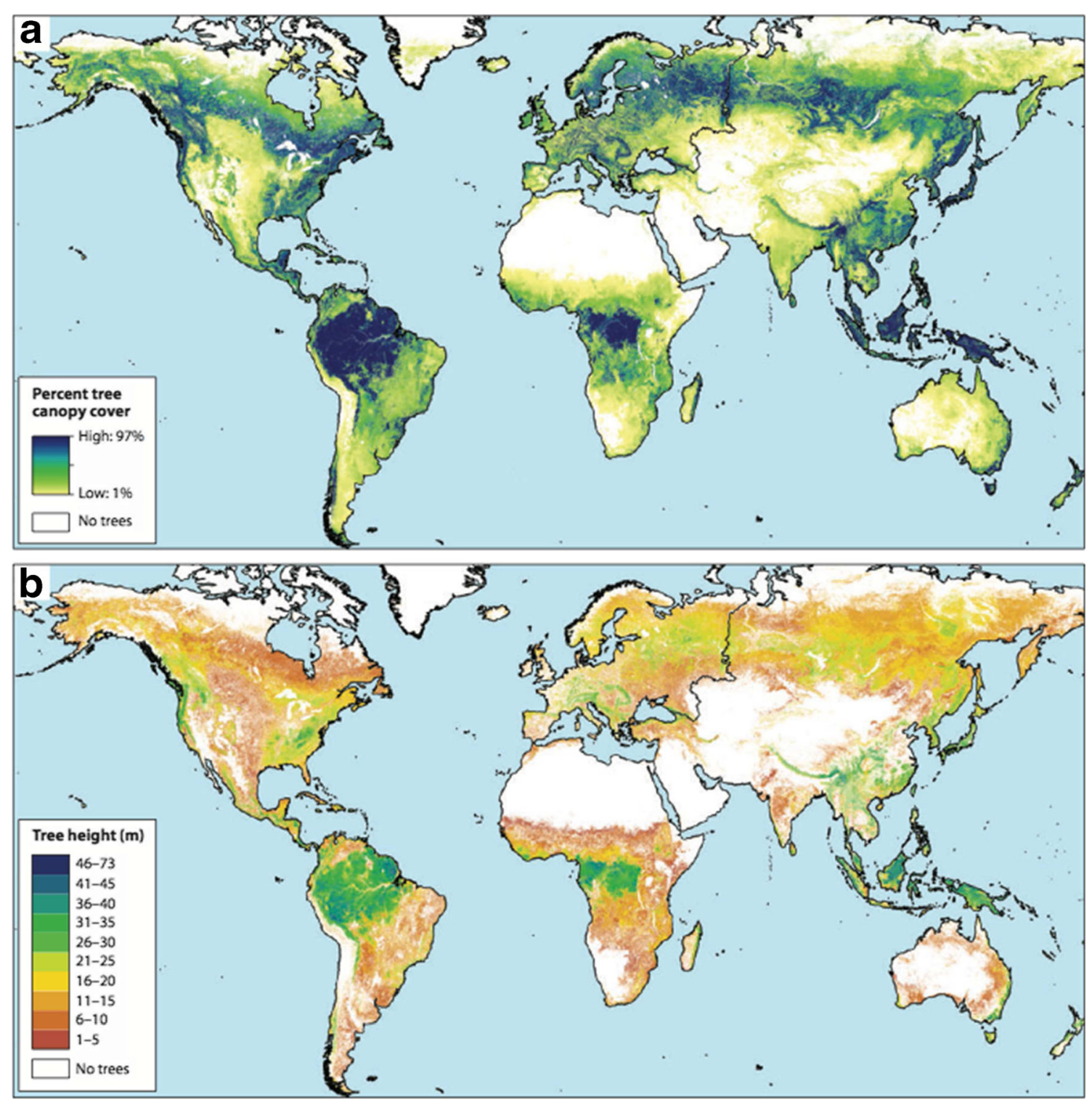

Fig. 2 a Percentage canopy cover derived from MODIS data [12••] and b global forest height map [13], based on the 90th percentile of ICESat GLAS height observations within a patch

SAR (PALSAR) data, maps of AGB have been generated at regional and country scales. For example, an AGB stratification map (up to $400 \mathrm{Mg} \mathrm{ha}^{-1}$ ) based on defined height ranges for each vegetation structural type was produced for Borneo in [24]. Comparisons with field estimates of AGB gave a standard error of predicted biomass of $53.2 \mathrm{Mg} \mathrm{ha}^{-1}$. In Gabon, AGB stocks were estimated at $78 \mathrm{Tg} \mathrm{C}$ (averaging $173 \mathrm{Mg} \mathrm{C} \mathrm{ha}{ }^{-1}$ ), which compared to a field average of $181 \mathrm{Mg} \mathrm{C} \mathrm{ha}^{-1}$; the overall uncertainty was $\pm 25 \%$ [25]. Airborne light detection and ranging (LiDAR) data have also been used to estimate tropical forest height over large areas, with this then related to AGB (e.g., [26]). In [26], AGB was converted to carbon units by taking $48 \%$ of the dry biomass. LiDAR-estimated AGB errors were of the order of $10 \%$ for any 1-ha land area (with RMSE ranging from 10.6 to 17.6 $\mathrm{Mg} \mathrm{C} \mathrm{ha}{ }^{-1}$ ). At the national level, the scaled average pixel level uncertainty for forests was estimated at $20.5 \mathrm{Mg} \mathrm{C} \mathrm{ha}{ }^{-1}$. A similar level of uncertainty was observed in deforested and dryland regions (with AGB $<20 \mathrm{Mg} \mathrm{Cha}^{-1}$ ) and areas dominated by small shrubs and grass cover (AGB $<5 \mathrm{Mg} \mathrm{C} \mathrm{ha}^{-1}$ ). In southern Nepal, [27] used a $5 \%$ LiDAR sample with forest inventory data to calibrate a Landsat-based AGB model ( $\mathrm{RMSE}=0.42, R^{2}=0.48$ at 1 -ha scale). By using these airborne/spaceborne LiDAR, the AGB estimates were extended beyond the saturation levels typically associated with optical and SAR sensor data.

Multi-frequency and interferometric SAR (InSAR) have also been applied to overcome saturation in the relationship 


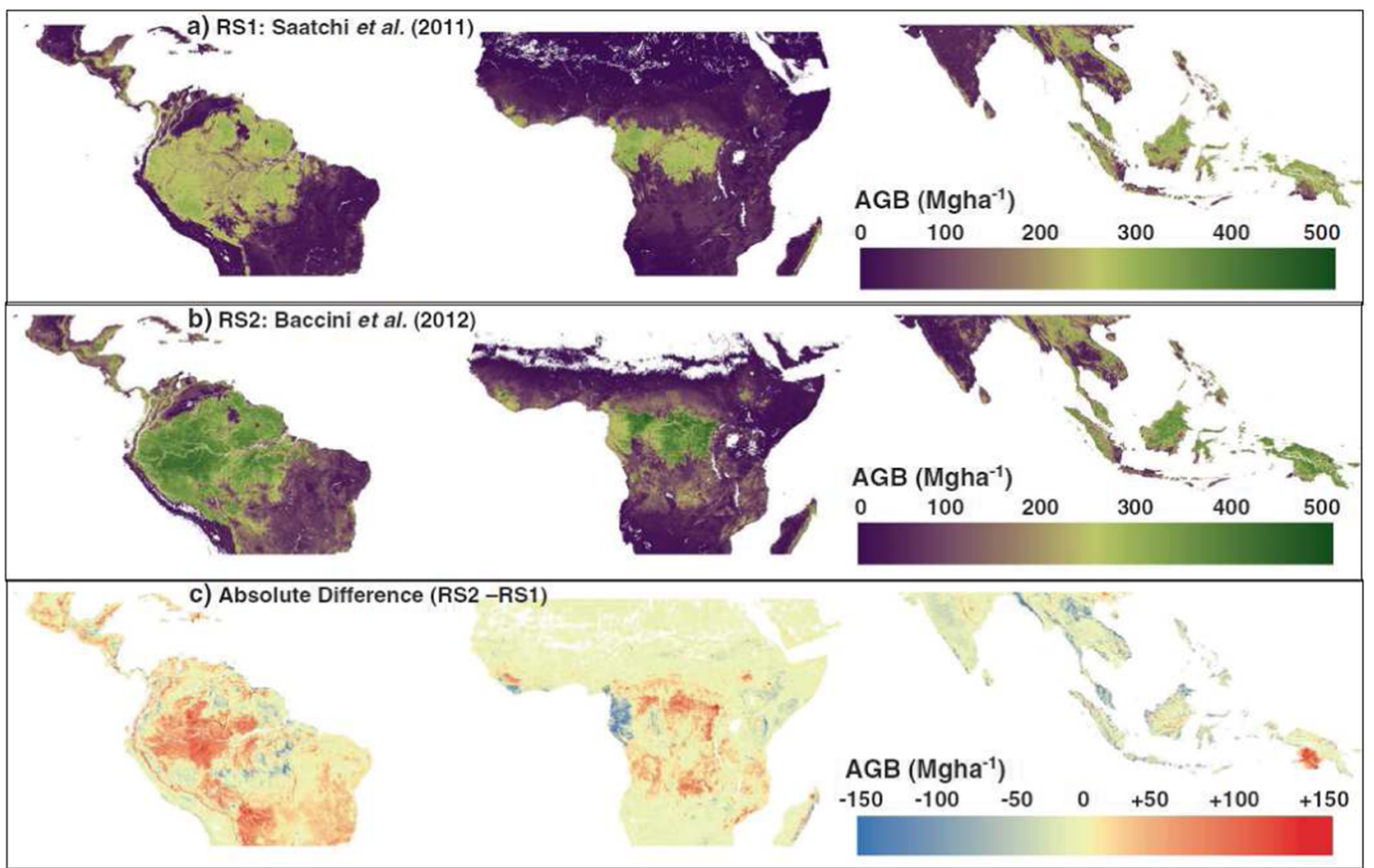

Fig. 3 A comparison of pan-tropical maps of AGB generated using ICESat GLAS, SRTM, and MODIS data [21 •, 22] and additionally, QuikSCAT data in [21•]. The absolute difference in AGB estimates is shown in $\mathbf{c}$; [23]

between SAR backscatter and AGB. [28], for example, demonstrated how TerraSAR-X (X-band) and ALOS PALSAR (L-band) data could be combined for large-scale AGB mapping in Kalimantan, Indonesia. The L-band data showed higher sensitivity to AGB but greater variance in low AGB ranges. Best results were obtained using a combined model $\left(R^{2}=0.53\right.$, RMSE $75.7 \mathrm{Mg} \mathrm{ha}^{-1}$, valid up to $307 \mathrm{Mg} \mathrm{ha}^{-1}$ with an accuracy requirement of $50 \mathrm{Mg} \mathrm{ha}^{-1}$ ). [29] demonstrated how the AGB of tropical forests in the Fly River, Papua New Guinea, could be recovered using airborne GeoSAR (X- and P-band) data. Forest AGB $\left(>150 \mathrm{Mg} \mathrm{ha}^{-1}\right)$ was estimated by applying a generic equation to a surrogate vegetation height, obtained from the difference in the Digital Surface Model (DSM) and Digital Terrain Model (DTM) at X- and Pband, respectively.

Optical data alone were used by [30] to estimate the AGB of vegetation in Colombia, including tropical rainforests and montane forests. Field biomass estimates revealed AGB ranges of $0.6-10 \mathrm{Mg} \mathrm{ha}^{-1}$ (grassland), $11-87 \mathrm{Mg} \mathrm{ha}^{-1}$ (secondary forest), and $98-397 \mathrm{Mg} \mathrm{ha}^{-1}$ (primary forest). An exponential model $\left(R^{2}=0.78\right.$ and 0.72 for primary and secondary forests, respectively; VCF $>40 \%$ ) was established, with this based on empirical relationships between ground-based AGB and the MODIS VCF product. Total AGB in Colombia was estimated at $16.2 \mathrm{Tg}$, with confidence intervals ranging from 3.7 to $25.0 \mathrm{Tg}$.

\section{Tropical/Subtropical Dry Broadleaved and Coniferous Forests}

These forests are widely distributed and are found in, for example, southern Mexico, southeastern Africa, central India, Indochina, Madagascar, New Caledonia, eastern Bolivia, central Brazil, the Caribbean, and along the coasts of Peru and Ecuador. In comparison to moist forests, fewer studies have focused on biomass estimation. For Mexico, [31] used ALOS PALSAR, Landsat-derived canopy density, SRTM elevation, and land use maps to extrapolate estimates of AGB from 26, 000 inventory plots; by using this combination, the saturation problem associated with the SAR data was largely overcome. AGB estimates were converted to above-ground carbon density using forest type-specific conversion factors, which ranged from 0.44 to 0.516 . While tropical/subtropical dry broadleaved and coniferous forests occupied much of the landscape, the mapping included humid tropical forests and mangroves. The majority of AGB was $<100 \mathrm{Mg} \mathrm{ha}^{-1}$ and the RMSE was $14 \mathrm{Mg} \mathrm{C}^{-1}$, with an $R^{2}$ of 0.5 and 0.34 for vegetation located on flat and steep terrain, respectively. The estimation bias was consistently low $\left(<3 \mathrm{Mg} \mathrm{C} \mathrm{ha}^{-1}\right)$. Other studies of subtropical and tropical dry forests have used LiDAR, SAR, or optical data with field measurements to estimate AGB. For tropical dry forests in the Yucatan Peninsula of Mexico, [32] used regression analysis to predict woody plant species richness and AGB from LiDAR metrics. The accuracy 
of AGB estimates improved with larger plot sizes (from 400 to $1000 \mathrm{~m}^{2}$ ), with RMSE decreasing from 37.4 to $19.8 \mathrm{Mg} \mathrm{ha}^{-1}$ (for the Kiuic site) and from 60.2 to $57.2 \mathrm{Mg} \mathrm{ha}^{-1}$ (for Felipe Carrillo Puerto). For tropical dry deciduous forests in central west India, [33] used multi-frequency (C-, L-, and P-band) airborne DLR-ESAR data to estimate AGB. Regression analysis revealed a significant correlation with biomass at $\mathrm{VV}$ polarization (all bands) and the saturation levels were 70 , 150, and up to $200 \mathrm{Mg} \mathrm{ha}^{-1}$ for C-, L-, and P-band, respectively. [34] estimated forest AGB in Cambodia using ALOS PALSAR 50-m mosaic and field inventory data. Strong relationships were found between L-band $\mathrm{HV}\left(R^{2}=0.67\right)$ and $\mathrm{HH} /$ $\mathrm{HV}\left(R^{2}=0.56\right)$ backscatter and field measurements of AGB. AGB was estimated to $200 \mathrm{Mg} \mathrm{ha}^{-1}\left(R^{2}\right.$ of 0.61 , RMSE of $\left.21 \mathrm{Mg} \mathrm{ha}^{-1}\right)$. For tropical dry forest in Peru, [35] utilized Landsat-7 ETM+ and derived vegetation indices to estimate the AGB, with best results obtained using the Enhanced Vegetation Index (EVI; $R^{2}=0.72$ and standard error, $\mathrm{SE}=20.95$ for overall biomass and $R^{2}=0.52$ and $\mathrm{SE}=23.9$ for tree biomass).

\section{Mangroves}

Mangroves are typically found in tropical and subtropical regions, with the majority located between $5^{\circ} \mathrm{N}$ and $5^{\circ} \mathrm{S}$ [36]. At a regional level, maps of mangrove canopy height have been generated by [37] using SRTM and ICESat GLAS data, with these converted to AGB through relationships with fieldbased heights. Using SRTM data calibrated with LiDAR and a high-resolution US Geological Survey (USGS) Digital Elevation Model (DEM), the mean tree height of mangrove forests within the Everglades National Park, Florida, was estimated with an RMSE of $2 \mathrm{~m}$ [38]. The standing biomass of the mangroves was then estimated using a relationship between mean height and field measured biomass $\left(R^{2}=0.82\right.$, RMSE of $37 \%$ ). The standard error of AGB estimates ranged from $\pm 20 \mathrm{Mg} \mathrm{ha}^{-1}$ (for stands with height=1 m) to $\pm 40 \mathrm{Mg} \mathrm{ha}^{-1}$ (height $=25 \mathrm{~m}$ ). [39] established a linear relationship between the ICESat GLAS canopy waveform contribution (CWC) and SRTM elevation to estimate mangrove canopy height $\left(R^{2}=\right.$ 0.85) in Colombia. Field data and allometrics were used to establish an empirical relationship between canopy height and AGB, which was subsequently scaled to map AGB across the wider landscape. Total biomass estimates varied between 1.2 and $1.7 \mathrm{Tg}$ depending upon the allometric equations used (residual RMS of 17.3 and 18.6; correlation coefficient, $r$, of 0.67 and 0.9). For Mozambique,[40] calibrated SRTM elevation data using a Landsat-derived land cover map and height calibration equations. Field measurements and published allometric equations were then applied to map the spatial distribution of biomass within the mangrove forest. Mozambique's mangroves extended $2700 \mathrm{~km}$ along the coast, with a total estimated AGB of 23.6 Tg. Mangrove canopy heights ranged from 1 to $27 \mathrm{~m}$, with an average of $5.8 \mathrm{~m}$, and AGB estimates ranged from 72 to $207 \mathrm{Mg} \mathrm{ha}^{-1}$ (average $=81 \mathrm{Mg} \mathrm{ha}^{-1}$ ).

In Australia, [41] improved estimates of AGB by combining SRTM-derived height maps with ALOS PALSAR backscatter data. All tall $(>\sim 10 \mathrm{~m})$ mangroves with prop root systems supported a backscatter that was lower than those without and which decreased in proportion to the AGB. [42] used maps of mangrove extent (from Landsat), ICESat GLAS, SRTM, and field data to generate maps of mangrove canopy height (RMSE $3.55 \mathrm{~m}$ ) for Africa. LiDAR-derived height estimates were then related to AGB using allometric models (RMSE of $65.4 \mathrm{Mg} \mathrm{ha}^{-1}$ ). At a global level, [43] predicted the potential mangrove AGB using a climate-based model in BIOCLIM and field data on carbon storage and fluxes in mangroves; remote sensing data were not utilized. A total global mangrove AGB of $2.83 \mathrm{Pg}$ was reported.

\section{Tropical/Subtropical and Temperate Grasslands, Savannas, and Shrublands}

These ecoregions are found in tropical and subtropical areas where rainfall is generally exceeded by evaporation and forests are typically characterized by their more open canopies [44]. For estimating AGB, methods have focused primarily on multi-sensor approaches that integrate optical, SAR, and/or LiDAR data. For savanna woodlands in Cameroon, [45] estimated the AGB $\left(<100 \mathrm{Mg} \mathrm{ha}^{-1}\right)$ using speckle-reduced ALOS PALSAR data and a regression model developed with groundbased estimates of AGB. A total AGB of 1.25 $\pm 0.04 \mathrm{Pg}$ was estimated, with a mean RMSE of $26.4 \pm 3.7 \mathrm{Mg}^{-1}$. In Australia, [46•] established that ALOS PALSAR data acquired under relatively dry conditions facilitated estimation of AGB. However, better estimates were obtained by first segmenting the landscape using a combination of ALOS PALSAR HH and HV backscatter and Landsat-derived fractional cover [47], classifying all segments using a hierarchical clustering procedure and then associating each class with an ICESat GLAS waveform. AGB was then considered to be a function of the fractional cover, L-band $\mathrm{HH}$ and $\mathrm{HV}$ backscatter and height metrics. [48] adapted a forward parametric model to derive a relationship between ALOS PALSAR HV backscatter intensity and field biomass $\left(R^{2}=0.92\right)$ for tropical lowland pine savannas in Belize. Over $90 \%$ of the woodlands were predicted to have an $\mathrm{AGB}<60 \mathrm{Mg} \mathrm{ha}^{-1}$, with an average AGB of $23.5 \mathrm{Mg} \mathrm{ha}^{-1}$. Compared to field measurements, errors of $<20 \%$ in predicted AGB were observed in the $100-\mathrm{m}$ resolution product. AGB estimates could be predicted with an RMSE of $13.5 \mathrm{Mg} \mathrm{ha}^{-1}$, and $80 \%$ of AGB estimates were found to have an error of $<20 \mathrm{Mg} \mathrm{ha}^{-1}$. In [49], a backcalibration method was used to estimate biomass in a forestsavanna boundary region in central Cameroon using L-band SAR data from Japanese Earth Resources Satellite (JERS-1) and ALOS PALSAR. The RMSE varied from $25 \%$ for AGB 
$<100 \mathrm{Mg} \mathrm{ha}^{-1}$ to $\sim 40 \%$ for $\mathrm{AGB}>100 \mathrm{Mg} \mathrm{ha}^{-1}$ using the ALOS PALSAR HV data. Changes in broad AGB classes in forest-savanna transition areas were detected with an accuracy of $>95 \%$.

To estimate the AGB of savannas in Colombia, [30] used a model that integrated both the EVI and MODIS VCF, with the inter-annual average of retrieved AGB used because of variations in EVI over time. Confidence intervals of the regression were larger as the AGB values increased. The uncertainty was estimated at 3.7 to $25.2 \mathrm{Tg}$, with a mean of $16.2 \mathrm{Tg}$. [50] modeled the woody AGB across South Africa by integrating MODIS canopy cover and ICESat GLAS-derived tree height. [51] established a correlation between Landsat Normalized Difference Vegetation Index (NDVI) and field measurements to estimate AGB in the sub-tropical rangelands of Argentina and a significant but weak relationship was reported $\left(R^{2}=0.5\right.$, $P=0.05)$.

\section{Mediterranean Forests, Woodlands, and Scrub}

Mediterranean forests have received little attention compared to other forest types [52], partly because the complexity of the terrain, environmental conditions, and heterogeneity (in terms of species and structure) of these forests presents major difficulties for consistent estimation of AGB over large areas [53]. Most studies have focused on modeled relationships between optical data field measurements of AGB. For Cistus scrub in southeastern Portugal, [54] exploited seasonal differences in the Landsat NDVI to map AGB and $74 \%$ of estimates were within $50 \%$ of the reference measurements $\left(R^{2}=0.75\right)$. For Mediterranean pine forests in northeastern Spain, [53] generated maps of forest residual biomass (FRB; comprising branches, foliage, and unmerchantable stem tops) using a multiple linear regression between Landsat-5 TM data and forest inventory data (relative RMSE of $26.7 \%$ or $4.8 \mathrm{Mg} \mathrm{ha}^{-1}, R^{2}=$ 0.71). Near Tuscany, Italy, [55] established relationships between vegetation parameters (height, cover, and diameter) and AGB in two size classes of vascular plants. A relationship between Quickbird-derived NDVI and AGB was then used to map fine $\left(0.02-20 \mathrm{Mg} \mathrm{ha}^{-1}\right)$ and coarse fuel biomass $(0$ $320 \mathrm{Mg} \mathrm{ha}^{-1}$ ), with an $R^{2}$ of 0.7 and 0.61 , respectively.

A few studies have considered the use of LiDAR or SAR data. For Mediterranean forests in central Spain, [56] estimated AGB fractions using small footprint discrete return LIDAR intensity data; species-specific models outperformed generic models (with $R^{2}$ values $>0.7$ ). RMSE values for AGB ranged between 9.7 and $18.5 \mathrm{Mg} \mathrm{ha}^{-1}$ for stands dominated by Holm oak (Quercus ilex) and black pine (Pinus nigra), respectively.[57] estimated the AGB of mixed shrublands and grasslands in central Israel through inversion of a semiempirical backscatter model using European Remote Sensing Satellite (ERS-2) SAR data, with the relationship between predicted and measured herbaceous biomass being stronger for homogenous $\left(R^{2}=0.9\right)$ compared to heterogeneous plots $\left(R^{2}=0.79\right)$.

\section{Temperate (Broadleaved, Coniferous, Mixed) and Boreal Forests}

For temperate and boreal forests, active remote sensing data have proved particularly useful for AGB estimation. For temperate forests of the northeastern USA, [58] estimated AGB using ALOS PALSAR data and a semi-empirical model based on ground observations. AGB was best estimated using the $\mathrm{HV}$ rather than $\mathrm{HH}$ polarization and the accuracy of estimates was improved by aggregating maps to the county scale ( $\left.\mathrm{RMSE}=12.9 \mathrm{Mg} \mathrm{ha}^{-1}, R^{2}=0.86\right)$. For temperate coniferous forest in British Colombia, Canada, [59] reported that a LiDAR-based model (RMSE 7.1-11.7 \%) could be improved with the addition of C-band SAR variables. However, in other studies, the integration of LiDAR canopy height and SAR data did not always increase the accuracy of AGB retrieval $[60,61]$. Optical data have also proved useful for AGB estimation in these biomes. As an example, and for the conterminous USA, Alaska, and also Puerto Rico, [62] modeled the AGB using MODIS, land cover, topographic, climate layers, and field plot data. The accuracy of predictions varied (e.g., $r$ ranging from 0.31 to 0.73 ) and overall, the model over- and under-predicted in low and high AGB areas, respectively. For continental China, [63] spatially quantified forest AGB at $0.05^{\circ}$ resolution using the MODIS land cover type product (MCD12C1) and national forest inventory data $\left(R^{2}=0.76\right)$. Total forest carbon stocks were estimated at $11.9 \mathrm{Pg}$, with an average of $76.3 \mathrm{Mg} \mathrm{ha}^{-1}$.

Although the aforementioned studies have focused primarily on temperate forests, many have also encompassed boreal forests and vice versa because of their proximity in many regions. For estimating the AGB of both forest biomes, significant use has been made of optical reflectance data. For example, [64] used global NOAAAVHRR-derived datasets at $8 \times 8 \mathrm{~km}$ resolution to quantify above-ground stump biomass (AGBs) over decadal periods and across six countries (Canada, Finland, Norway, Russia, Sweden, and the USA) where needle and broad leaved forests predominated. AGBs included all woody material, excluding roots, estimated from inventories of wood volume. AGBs were estimated using the maximum NDVI cumulated over growing seasons for a 5year period. The AGBs associated with a given level of NDVI varied with latitude, with the largest values being in temperate zones; hence, latitude was also included as a parameter in the retrieval. The average absolute difference between remote sensing and inventory estimates was $10.4 \mathrm{Mg} \mathrm{Cha}^{-1}$ (AGBs), 16.1 $\mathrm{Mg} \mathrm{C} \mathrm{ha}^{-1}$ (total AGB), and $0.33 \mathrm{Mg} \mathrm{C} \mathrm{ha}^{-1}$ year $^{-1}$ (changes in pool size) or 27, 33, and $50 \%$ of the mean inventory estimates, respectively. [65] mapped the spatial distribution of AGB in Russia at 500-m resolution by first regressing 
field-derived wood volume against MODIS BRDF (16-day composite) data and then using the results to assign an AGB value to forest pixels identified on the GLC2000 and MOD12Q1 land cover maps. AGB estimates varied between 46 and $67 \mathrm{Pg}$, due largely to difference in the definition of forest area. The error of AGB estimates was $~ 40 \%$, and was greater within the closed canopy forests. The MODIS data were successful in capturing gross differences in AGB across broad environmental gradients and for different forest structures [65].

SAR has often been the sensor of choice for estimating the AGB of boreal and temperate forests (e.g., [66-68]), although studies have generally focused on sub-regions rather than the whole biome. For example, the European Commission SIBERIA project aimed to map approximately 1 million $\mathrm{km}^{2}$ of the Siberian landmass using data from the ERS- $1 / 2$ and the JERS1 SAR. A limitation of using the JERS-1 SAR data was that saturation of the L-band $\mathrm{HH}$ response occurred at 40 $50 \mathrm{Mg} \mathrm{ha}^{-1}$ (equivalent to $80 \mathrm{~m}^{3} \mathrm{ha}^{-1}$ of growing stock volume or GSV). For this reason, ERS-1/2 interferometric coherence data were used and were found to be significantly lower over closed compared to open forest canopies. For forest classes with a GSV of up to $80 \mathrm{~m}^{3} \mathrm{ha}^{-1}$, accuracies of over $80 \%$ were achieved for over 100 ERS frames [67].

For the pan-boreal region (North America, Europe and Asia covering the latitudes of $30^{\circ} \mathrm{N}$ and $80^{\circ} \mathrm{N}$ ), [69॰] estimated GSV at $0.01^{\circ}$ resolution from ENVISAT Advanced Synthetic Aperture Radar (ASAR) using the BIOMASAR algorithm $[69 \bullet, 70]$. The algorithm is advantageous as it can be implemented without the need for calibration data. GSV was mapped without saturation up to $300 \mathrm{~m}^{3} \mathrm{ha}^{-1}$ but less than $1 \%$ had a GSV above this value. The RMSE was 34.2-48.1\% (1-km pixels), but with $10 \%$ uncertainty applied to temporal data. Annual, global mapping of the GSV of boreal forests using a hyper-temporal stack ( $>20$ images) of C-band observations was considered realistic, particularly following successful launch of the Sentinel-1 ScanSAR in 2014.

Around $80 \%$ of the AGB is contained within the stems [71] and expansion factors can be used to convert GSV to AGB $[72,73]$. On this basis, [17•] took the GSV estimates of [69•] to generate a map of boreal and temperate forest stock and carbon density (Fig. 4). There was good agreement between the carbon density map and inventory data at regional scales $\left(R^{2}\right.$ of $\left.0.7-0.9\right)$. The relative uncertainty of the stem carbon map was below $20 \%$ in most areas, except for broadleaf trees where the high variation in wood density caused higher uncertainties. The algorithm could be improved if a consistent global dominant tree species map was available.

InSAR has also been used for large area mapping of AGB on the basis that the surrogate vegetation height inferred from interferometric pairs relates to AGB [74]. For example, [75] generated an above-ground carbon (AGC) dataset for the conterminous USA using national forest inventory, SRTM, and
Landsat data. The RMSE varied with the scale of estimates, being $55 \mathrm{Mg} \mathrm{ha}^{-1}$ (plot scale), $19 \mathrm{Mg} \mathrm{ha}^{-1}$ (hexagon), $14 \mathrm{Mg} \mathrm{ha}^{-1}$ (country), and $12 \mathrm{Mg} \mathrm{ha}^{-1}$ (State).

A number of regional-scale studies have applied airborne LiDAR technology singularly (e.g., $[76,77 \bullet])$ or in combination with other satellite (SAR and optical) and field inventory data (e.g., $[59,78]$ ) to estimate AGB in boreal forests. As examples of singular use, [76, 77•] used LiDAR strip sand field inventory data to estimate AGB in Norway and interior Alaska, respectively. Both design- and model-based estimators were used, with these considered transferrable to other regions (e.g., the tropics). In [77•], the standard errors of AGB change estimates over an 11-year period were reduced by $18-84 \%$ compared to field survey estimates. The modelassisted estimate of loss in biomass for all change categories (deforestation, degradation, undisturbed) was $11.9 \mathrm{Mg} \mathrm{ha}^{-1}$ $(\mathrm{SE}=1.6)$ compared to the field-based estimate of 17.8 $\mathrm{Mg} \mathrm{ha}^{-1}(\mathrm{SE}=3.7)$ when using linear models. In [76], the LiDAR-assisted model estimate of AGB was $35.7 \mathrm{Tg}$, with a relative SE of $11 \%$. Over expansive areas of birch forest in Sweden, [79] demonstrated that AGB could be retrieved using LiDAR data collected with a sparse point density, achieving RMSEs of 8.8 and $9.5 \%$ for tree height and 18.7 and $21.2 \%$ for AGB for dense ( 6.1 points $\left.\mathrm{m}^{-2}\right)$ and sparse (1.4 points $\mathrm{m}^{-2}$ ) scans, respectively. Such sample-based approaches may present a viable approach to large-area AGB mapping; a domain once previously thought to be limited to satellite technology/methods.

Many studies have demonstrated and advocated data fusion approaches for AGB estimation over boreal forests. [78] highlighted the potential of radargrammetry (using TerraSAR-X Spotlight data) in combination with a LiDAR DTM for large-area estimation of AGB in southern Finland (RMSE of $41.3 \mathrm{Mg} \mathrm{ha}^{-1}$ ). InSAR height models retrieved using TanDEM-X data with a reference LiDAR DTM enabled the AGB of a spruce forest in southeast Norway to be estimated with an RMSE of $\sim 44 \%$ (plot level) and $20 \%$ (stand level); [80]. For boreal hardwood forests in Maine, USA,[81] reported reduced errors $\left(12-38 \%, 11-28 \mathrm{Mg} \mathrm{ha}^{-1}\right)$ in AGB estimates when LiDAR was combined with UAVSAR (Lband) or Landsat data. In a similar study, [82] improved AGB estimates (RMSE $31.3 \mathrm{Mg} \mathrm{ha}^{-1}$ up to AGB of 200 $250 \mathrm{Mg} \mathrm{ha}^{-1}$ ) were obtained through the synergistic use of LiDAR and ALOS PALSAR data.

\section{Global Estimates}

To estimate AGB at the global level, both sample-based and spatially explicit methods have been adopted, but the use of remote sensing data has been compromised by inconsistencies in satellite data coverage, lack of long-term continuity of satellite sensor data, and derived global land cover products, and insufficient in situ observations for algorithm development. 


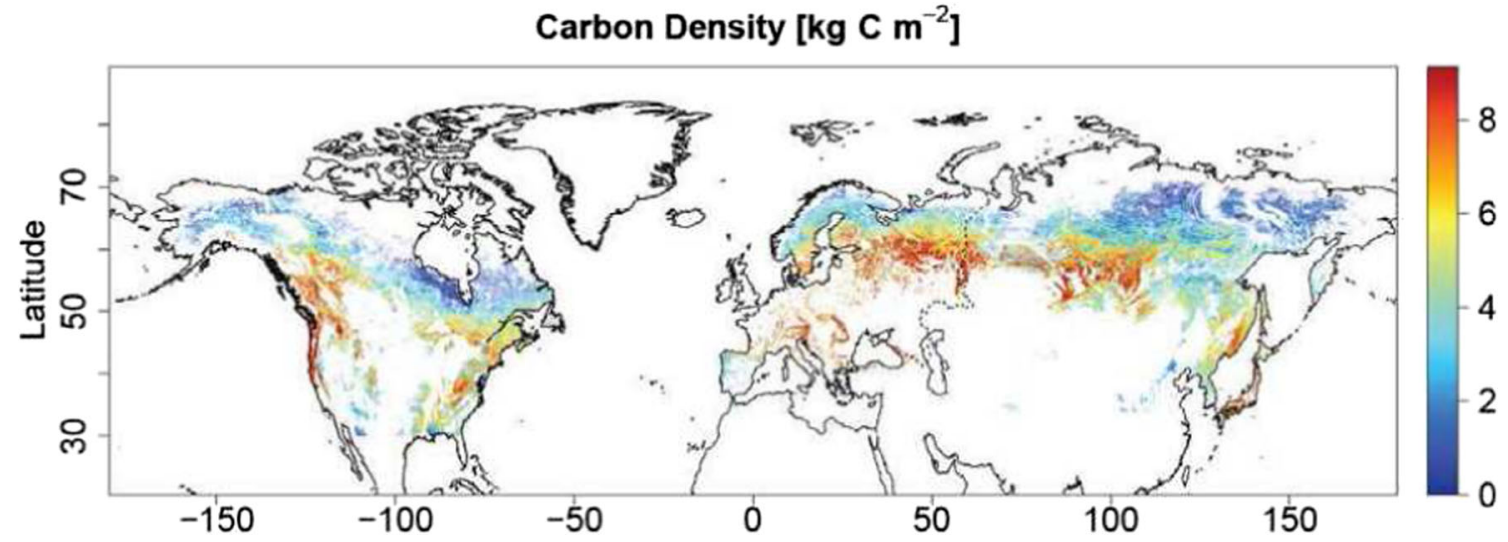

Fig. 4 Total forest carbon density in northern hemisphere boreal and temperate forests [17•]

The aggregated country-level biomass/carbon stock estimates available through the FAO Global Forest Resources Assessments (FRA) represents a sample-based approach for estimating forest AGB at the country level. The FRA 2005 dataset was downscaled by [83] to generate a global $0.5^{\circ}$ resolution map of global forest area (in this case, 3980 million ha), GSV $\left(466 \times 10^{9} \mathrm{~m}^{3}\right), \operatorname{AGB}\left(472 \times 10^{9} \mathrm{Mg}\right)$, and AGC $\left(234 \times 10^{9} \mathrm{Mg}\right.$ C). Values for global forest area $(+0.69 \%)$ and GSV (+ $5.25 \%$ ) were higher than those reported in the FRA 2005. For 2000, [84] produced a Tier 1 global carbon density map (Fig. 5). In this two-step process, vegetation carbon stocks were estimated using IPCC global default values and spatial map data (on a $1 \times 1 \mathrm{~km}$ grid) were produced using a variety of climate and vegetation (e.g., GLC2000, FAO ecofloristic zones and forest age) datasets. The conversion of biomass to carbon stocks was specific to each continent, ecoregion, and vegetation type. This Tier 1 method $([84,85])$ was also used to create gridded biomass and carbon stock maps for continental Europe [86] and is considered a cost-effective approach to large-scale (continental-global) mapping of forest biomass/ carbon stocks.

The only method to use globally available remote sensing data was developed by [87] who used passive microwave derived Vegetation Optical Depth (VOD) from the 1990s onwards to retrieve above-ground biomass carbon (ABC) for all vegetation types, albeit at $>10 \mathrm{~km}$ spatial resolution. The advantage of the VOD is that it maintains sensitivity at high biomass density levels (e.g., in rainforests). VOD estimates were synthesized from a range of passive microwave satellite sensors (e.g., SSM/I, AMSR-E, MWRI, and Windsat) and converted to AGB through calibration with the AGB map of $[21 \bullet]$.

\section{Summary of Methods by Forest Type}

Approaches to the estimation of AGB at various scales and for different forest types are summarized in Table 1 . Where forests are tall and complex, as in the case of the rainforests of the

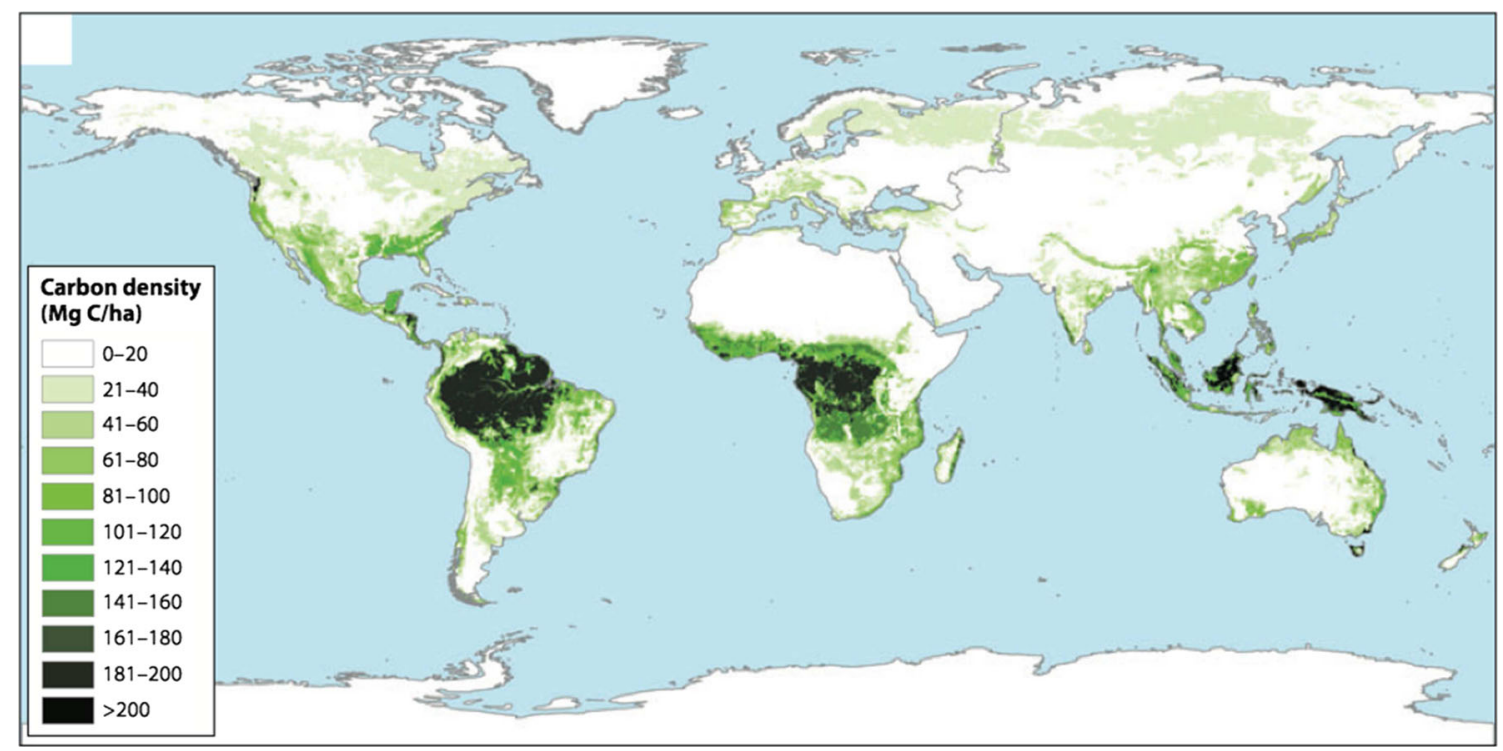

Fig. 5 The distribution of carbon at a global level [84] 
Table 1 Summary of approaches to above-ground biomass estimation for different forest types

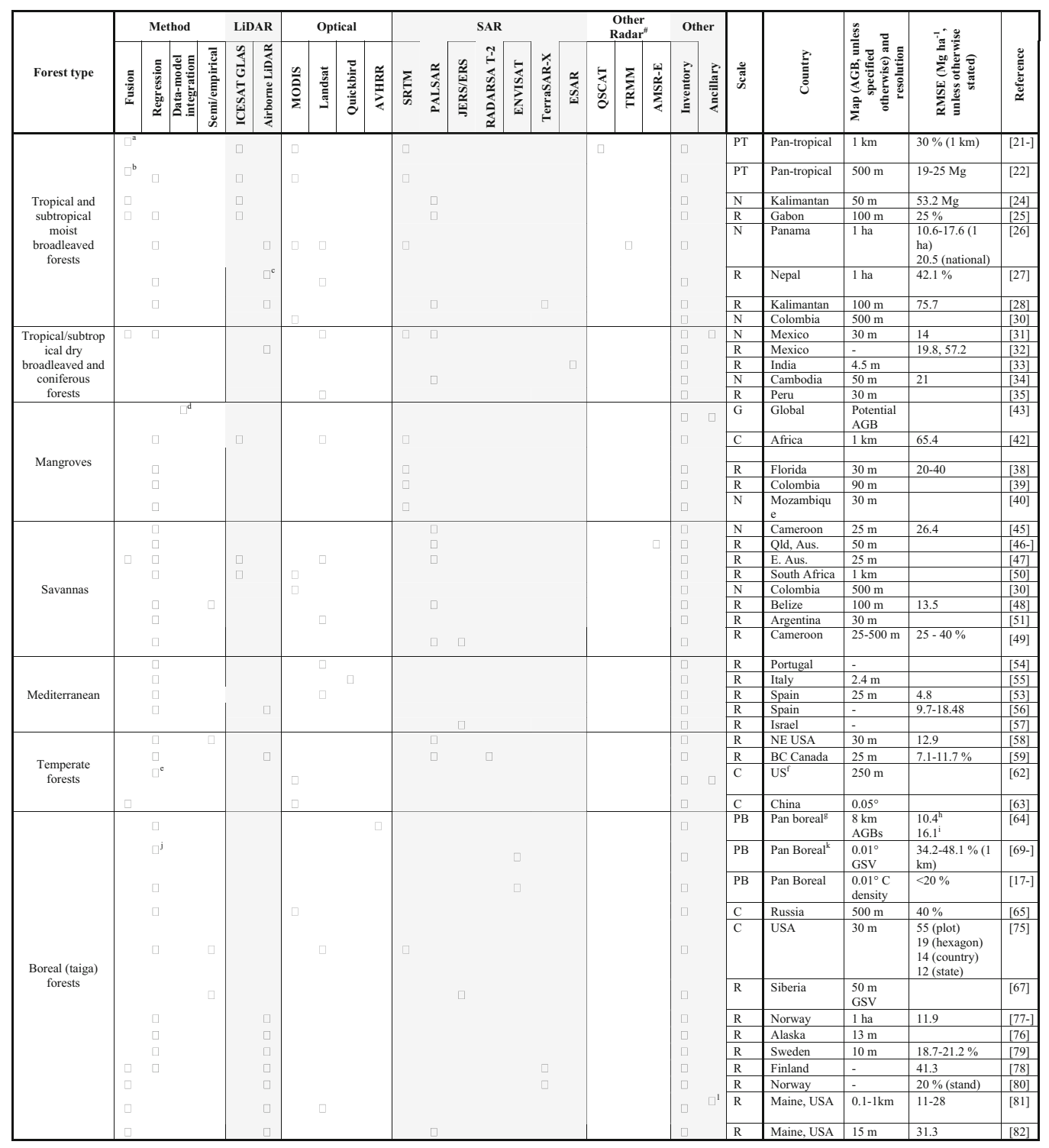

The class of AGB mapping method, remote sensing data used, country, scale of application, and RMSE (where reported) are listed for each of the studies identified by this review

$G$ global, $P T$ pan-tropical, $P B$ pan-boreal, $C$ continental, $N$ national, $R$ regional

${ }^{\text {a }}$ Maxent

${ }^{\mathrm{b}}$ Random forests

c $5 \%$ sample

${ }^{\mathrm{d}}$ Bioclim

e See5 and Cubist

${ }^{\mathrm{f}}$ Includes Alaska and Puerto Rico

${ }^{g}$ Canada, Finland, Norway, Russia, Sweden, USA

${ }^{\mathrm{h}}$ AGB (stumps)

${ }^{\mathrm{i}}$ Total AGB

${ }^{\mathrm{j}}$ BIOMASAR

${ }^{\mathrm{k}}$ North America, Europe, Asia

${ }^{1}$ UAVSAR

${ }^{\#}$ Other radar: includes scatterometers and radiometers 
humid tropics and subtropics, ICESat GLAS data have often been integrated within retrieval algorithms. These data have also been used in combination with other data (e.g., L-band SAR) to support the retrieval of structural attributes (e.g., height) in wooded savannas (e.g., in southern Africa and Australia), from which AGB has been derived subsequently. Lower frequency L-band SAR data (primarily HV polarization) have been used primarily to retrieve the AGB of lower stature forests, including regrowth and savannas, where the AGB is typically below the observed saturation levels; however, the uncertainty has typically been high [88]. For boreal and temperate regions, ICESat GLAS data have rarely been used, with focus being more on ALOS PALSAR and higher frequency $\mathrm{X}$ - and C-band SAR data and derived measures (e.g., coherence); some use has also been made of optical (e.g., MODIS) data. Optical data have also been used for estimating the AGB of forests with a relatively simple stand structure and gradients of cover [89], as in the case of Mediterranean woodlands or wooded savannas. In the majority of studies, data have been integrated from different sensors as this overcomes sensorspecific limitations such as saturation, operating modes, and temporal gaps [90]; however, this often limits the repeatability of such approaches over time.

Airborne data have been exploited in many regions, with both InSAR and LIDAR used to recover height and/or AGB, either in wall-to-wall mapping or sampled approaches. The success of InSAR techniques is dependent largely on site conditions (e.g., wind speed and soil/canopy moisture) and timing of acquisitions, but AGB has been successfully retrieved (e.g., in boreal forests [88]). Measurement accuracy decreases where there is a change in target properties between acquisitions (i.e., temporal decorrelation, which is often the case in repeat-pass interferometry). This is less of an issue when using single-pass methods, whereby images are acquired simultaneously by two antennas. LiDAR and SAR data are used extensively for biomass estimation in temperate and boreal forests. LiDAR is, however, currently restricted to airborne platforms (with ICESat GLAS no longer operational) and limited by cost, and so, most studies have used sample-based approaches. Regression techniques are commonly used to establish relationships between LiDAR-derived height metrics and AGB at the tree clump or stand scale, with the resulting estimates often used in combination with error propagation to support extrapolation by way of spaceborne sensors. The use of C- and X-band SAR is limited to low biomass forests but there have been successful demonstrations of AGB estimation in boreal forests at pan-boreal and regional scales using multitemporal C-band data.

\section{The Influence of Environmental Conditions}

When retrieving AGB across large areas, the variations in environmental conditions can influence the outcome. For eastern
Australia, [46 $]$ established that surface moisture conditions influenced the ability to retrieve biomass using ALOS PALSAR data, with the use of scenes acquired under the driest conditions being preferable. Wet conditions resulted in stripping in regional mosaics of ALOS PALSAR data, which was most evident in dry and open forest environments. Therefore, the development of AGB retrieval algorithms using these data needs to ensure that the conditions are suitable. [31] noted that the lack of consistent temporal data was limiting AGB estimation from SAR data, with retrieval accuracies dependent on imaging conditions on a per scene basis. Topographic relief causes foreshortening and shadowing of SAR imagery and also leads to incorrect retrieval of height profiles and metrics from ICESat GLAS data. InSAR height estimation techniques are affected by wind and on-ground change and the interval between observations should be as reduced (e.g., to 1 day) for best results. Other factors complicating the retrieval of AGB include freeze/thaw conditions [69॰], the presence of snow and cloud cover, and inundation below the forest. In the latter case, double bounce scattering [41] between tree trunks and the water surface enhances the SAR backscattered signal particularly at lower (e.g., L-band frequencies) and leads to overestimation of AGB.

\section{Where is the Biomass?}

On the basis of remote sensing estimates, [87] estimated the global distribution of total above-ground biomass carbon (ABC) for 1988-2002 to be $362 \mathrm{Pg} \mathrm{C}$, with $\sim 65 \%$ in forests and $17 \%$ in savannas. Comparable estimates were obtained for the different forest biomes in related studies (e.g., [2••, 21•, 22]; Table 2). For the pan-tropics and at the broad level, estimates by $[21 \bullet, 22]$ were similar, but differences were evident in local distributions [23]. The distribution of $\mathrm{ABC}$ at the continental level was highest in Latin America (117.7 $\pm 8.4 \mathrm{Pg} \mathrm{C}$ ), followed by Africa (64.5 $\pm 8.4 \mathrm{Pg} \mathrm{C}$ ) and Asia (46.5 $\pm 3 \mathrm{Pg} \mathrm{C}$; [22]. Continental biomass was mostly stored in forests with $\mathrm{AGB}$ $>100 \mathrm{Mg} \mathrm{ha}^{-1}[21 \bullet]$, and nearly half the total AGB was stored in forests with $\mathrm{AGB}>250 \mathrm{Mg} \mathrm{ha}^{-1}$. Forests with $\mathrm{AGB}>$ $350 \mathrm{Mg} \mathrm{ha}^{-1}$ comprise $\sim 7-9 \%$ of total continental AGB.

Most of the AGB in temperate and boreal zones is located in north-west Canada and the USA; the European mountains (mostly temperate coniferous forest); European Russia; southern central Siberia (temperate, broadleaf, and mixed forests); and Japan (mostly temperate broadleaf and mixed forests) [17•]. In the boreal zone, forest biomass decreases moving north along a latitudinal gradient. [64] similarly found that Canada, China, Russia, and the USA contained $84 \%$ of the AGB in these zones. 79.8 Pg C was reported for northern boreal and temperate forests, with Asian boreal forests accounting for $22.1 \pm 8.3 \mathrm{Pg} \mathrm{C}$. [64] estimated the total carbon pool at $61 \pm 20 \mathrm{Pg} \mathrm{C}$, with larger pools in North America $\left(51 \mathrm{Mg} \mathrm{C} \mathrm{ha}^{-1}\right.$ ) compared to Eurasia (39 $\mathrm{Mg} \mathrm{C} \mathrm{ha}^{-1}$ ). 
Table 2 Forest carbon stocks by biome, as estimated using remote sensing data

\begin{tabular}{|c|c|c|c|c|c|c|}
\hline \multicolumn{6}{|c|}{ Total forest carbon (Pg C; 90th CI in brackets) } & \multirow[t]{2}{*}{ Reference } \\
\hline Global & Tropical & $\begin{array}{l}\text { Tropical/subtropical } \\
\text { savanna and shrubland }\end{array}$ & Boreal & Temperate & Mangroves & \\
\hline $362^{\mathrm{b}}(310-422)$ & $195(180-208)$ & $49(42-56)$ & $44(37-66)$ & $36.4(24-39)$ & & [87] \\
\hline \multirow[t]{6}{*}{$362.6^{\mathrm{a}, \mathrm{c}}$} & 262.1 & & 53.9 & 46.6 & & {$[2 \bullet \bullet]$} \\
\hline & 247 & & & & & {$[21 \bullet]$} \\
\hline & 228.7 & & & & & {$[22]$} \\
\hline & & & 40.8 & 39 & & {$[17 \bullet]$} \\
\hline & & & $61 \pm 20^{\mathrm{d}}$ & & & [64] \\
\hline & & & & & $2.83(2.18-3.4)$ & {$[43]$} \\
\hline \multicolumn{7}{|c|}{${ }^{\mathrm{a}}$ Includes above and below ground live biomass } \\
\hline \multicolumn{7}{|l|}{ b $1998-2002$} \\
\hline \multicolumn{7}{|l|}{${ }^{\mathrm{c}} 2007$} \\
\hline${ }^{\mathrm{d}}$ Includes boreal & mperate & & & & & \\
\hline
\end{tabular}

For mangroves, [43] estimated the total global AGB as $2.83 \mathrm{Pg}$ with an average AGB of $184.8 \mathrm{Mg} \mathrm{ha}^{-1}\left(\mathrm{CI}_{95}\right.$ 142.1-222 $\mathrm{Mg} \mathrm{ha}^{-1}$ ). The largest mangrove extent was found in SE Asia, and accounted for approximately half of the total global AGB for this forest type. Mangroves were considered to contribute $1.4 \%$ of global tropical forest AGB and $1.6 \%$ of the total tropical forest biomass (above- and below-ground). Mangroves of low AGB $\left(<80 \mathrm{Mg} \mathrm{ha}^{-1}\right)$ were found at the limits of their distribution, which were largely governed by temperature. Mangroves with the highest AGB $\left(>280 \mathrm{Mg} \mathrm{ha}^{-1}\right)$ were found in tropical areas with high annual rainfall.

\section{Trends in Global Biomass}

There are limited remote sensing-based evaluations of trends in global forest biomass. This can be attributed in part to inadequate and inconsistent satellite coverage (both spatially and temporally), uncertainty of retrieval algorithms across forest types, and changing environmental conditions between observation periods. Even studies conducted at localregional scale are few, and use, for example, repeat LiDAR (e.g., $[91,92])$ or SAR data (e.g., $[93,94])$.

The only known attempt to estimate global above-ground carbon $(\mathrm{ABC})$ change used passive microwave VOD data acquired over two decades [87]. It was estimated that $0.07 \mathrm{Pg} \mathrm{C}_{\text {year }}{ }^{-1} \mathrm{ABC}$ was lost globally between 1993 and 2012, with most losses associated with tropical forests $\left(-0.26 \mathrm{Pg} \mathrm{C}_{\text {year }}{ }^{-1}\right)$. Net gains were reported for boreal and temperate forests $\left(+0.013 \mathrm{Pg} \mathrm{C}\right.$ year $\left.^{-1}\right)$ and tropical savannas and shrublands ( $\left.+0.05 \mathrm{Pg} \mathrm{C}_{\text {year }}{ }^{-1}\right)$. The global trends in $\mathrm{ABC}$ change were attributed largely to tropical deforestation, rainfall variability in savannas and shrublands, regrowth on abandoned lands, and pest attacks and wildfires in boreal and temperate regions [95].

Alternate sources of trend information can be found in the successive FAO global forest resource assessments (FRA), conducted since 1990. Over the period 1990-2005, a decrease in forest growing stock in Africa, Asia, and South America and a net increase in other regions was observed [96]. Similar trends were observed over the period 2005-2010 [97], with the exception of Asia where planting of broadleaved species (mostly in China) has increased forest extent and biomass. Globally, forest growing stock decreased by $1.1 \mathrm{Pg}$ annually (1990-2005) and 0.5 Pg annually (2005-2010), largely attributed to deforestation and forest degradation (e.g., from selective logging, wild fire, and pests/diseases). Global forest biomass stock decreased by $\sim 23 \mathrm{Pg}(3.6 \%)$ over the period 1990-2010 [97], with the greatest losses being in Africa and South America. Total biomass stock increased in Europe and North America over the same period.

\section{New and Emerging Technology}

Several future satellites sensors are expected to revolutionize estimation of AGB at country to global scales (Table 3 ). The BIOMASS mission aims to produce maps of forest AGB (twice yearly) at 200-m resolution (with error not exceeding $\pm 20 \%$; or $10 \mathrm{Mg} \mathrm{ha}^{-1}$ ) and forest canopy height (with an expected accuracy of $\pm 4 \mathrm{~m}$; [98]). ICESat- 2 is the secondgeneration laser altimeter (http://icesat.gsfc.nasa.gov/ icesat2/), the Global Ecosystem Dynamics Investigation 
Table 3 Characteristics of future spaceborne sensors, either designed specifically for, or expected to contribute to AGB estimation

\begin{tabular}{|c|c|c|c|c|}
\hline Sensor & Space agency & $\begin{array}{l}\text { Proposed } \\
\text { launch }\end{array}$ & Platform & Characteristics \\
\hline BIOMASS & European Space Agency (ESA) & 2020 & - & 200-m spatial resolution \\
\hline $\begin{array}{l}\text { The Ice, Cloud, and land } \\
\text { Elevation Satellite-2 (ICESAT-2) }\end{array}$ & $\begin{array}{l}\text { National Aeronautics and } \\
\text { Space Administration (NASA) }\end{array}$ & 2017 & - & $\begin{array}{l}\text { 532-nm laser split into } 6 \text { beams, } \\
\text { arranged in } 3 \text { pairs; } 3.3 \mathrm{~km} \\
\text { between each pair. }\end{array}$ \\
\hline $\begin{array}{l}\text { Global Ecosystem Dynamics } \\
\text { Investigation (GEDI) }\end{array}$ & NASA & 2018 & International Space Station & $\begin{array}{l}3 \text { laser transmitters } \\
\text { producing } 14 \text { parallel tracks } \\
\text { of } 25-\mathrm{m} \text { footprints }\end{array}$ \\
\hline $\begin{array}{l}\text { Multi-footprint Observation } \\
\text { LiDAR (MOLI) }\end{array}$ & $\begin{array}{l}\text { Japanese Aerospace } \\
\text { Exploration Agency (JAXA) }\end{array}$ & 2018 & $\begin{array}{l}\text { International Space } \\
\text { Station }\end{array}$ & $\begin{array}{l}4 \text { laser transmitters, } \\
25 \text {-m footprints }\end{array}$ \\
\hline
\end{tabular}

(GEDI) is a multi-beam waveform LiDAR (http://science. nasa.gov/missions/gedi/), and the Multi-footprint Observation LiDAR (MOLI) is a waveform LiDAR combined with a high $(5 \mathrm{~m})$ resolution visible and near infrared (VNIR) imager [99]. These sensors will provide information on the heights of vegetation and the distribution of plant material within the vertical profile at local to global scales. In combination with optical (e.g., Landsat) time-series data (e.g., [100]), this will enable the AGB and changes occurring as a result of forest dynamics to be quantified, thereby allowing better assessments of carbon balances and sequestration potential as well as habitat quality and biodiversity. High-resolution products related to canopy height and carbon are also anticipated through fusion with other satellite sensor data (e.g., Sentinel1 SAR, TerraSAR-X).

Initiatives aimed at collating local to global scale in situ and remote sensing biomass datasets are also increasing, including the Biomass Geo-Wiki (http://biomass.geo-wiki.org/). Biomass data can be overlain on high-resolution imagery and queried against other available datasets (e.g., geo-tagged photographs, NDVI). Such a platform supports gap analysis, cross-product validation, and generation of hybrid products using existing datasets. Archives of LiDAR collated from purpose-built terrestrial and airborne platforms are also increasingly important in the validation and spatial extrapolation of AGB from satellite sensors. Notable examples include the US National Earth Observatory Network (NEON; http:// www.neoninc.org/), Australia's Terrestrial Ecosystem Research Network (TERN; http://www.tern.org.au/), and the Carnegie Airborne Observatory (CAO; https://cao. carnegiescience.edu/) in the context of REDD+. Terrestrial LiDAR data have also recently demonstrated near direct estimation of above-ground volume/AGB [101], which will reduce uncertainty propagated when using allometrics. Initiatives such as the Terrestrial Laser Scanning International Interest Group (TLSIIG; http://tlsiig.bu.edu/) are coordinating research in the development of low-cost sensors and benchmarking of AGB retrieval algorithms.

\section{Conclusions}

The review has highlighted the diversity of remote sensing algorithms and datasets that have been used to retrieve the AGB of the World's forests. Many approaches are reliant on regression analysis of field and remote sensing observations from single sensors. However, data fusion techniques that exploit the unique advantages of multiple sensors operating in different modes (optical, LiDAR, and radar) are extending estimates, particularly in the high biomass range. New and innovative algorithms for estimating AGB are also being developed, with these including the BIOMASAR, which ingests high temporal frequency Cband SAR and has shown application across the temperate/ boreal zone. While many studies attempt to retrieve AGB directly, estimates of structural attributes (e.g., height and cover derived from LiDAR and optical/SAR sensors, respectively) are increasingly being exploited to improve AGB estimates at country to regional scales. Airborne LiDAR data have been used alone for estimating AGB across large areas, including within sample-based approaches, or as a tool for calibrating models for retrieving AGB from spaceborne sensors.

The potential of many techniques (particularly those at high $(<30 \mathrm{~m})$ resolution) has not been evaluated at a global, let alone, regional level. This is because many have used particular datasets that have been developed for specific environments, with this due to funding and expertise; hence, their application to other environments has not been tested. Furthermore, by using relatively limited datasets to develop algorithms for regional application, many studies have not adequately considered the environmental conditions prevailing (both in the development and application process). However, with the increase in sensors acquiring at high temporal and spatial resolution [102], there is a significant opportunity for extracting quantitative statistics on amounts of and changes in forest cover and carbon stocks worldwide at these high resolutions. These opportunities are anticipated to increase following launch of new sensors such as the ICESAT-2, GEDI, MOLI, and BIOMASS. 


\section{Compliance with Ethics Guidelines}

Conflict of Interest Professor Lucas has no conflicts of interest to declare.

Human and Animal Rights and Informed Consent This article contains no studies with human or animal subjects performed by the author.

\section{References}

Papers of particular interest, published recently, have been highlighted as:

- Of importance

•- Of major importance

1. Shvidenko A, Barber CV, Persson R. Forests and woodland systems. Chapter 21. In: Hassan R, Scholes R, Ahs N, editors. Ecosystems and human well-being: current state and trends. Washington: Island Press; 2005.

2.• Pan Y, Birdsey RA, Phillips OL, Jackson RB. The structure, distribution, and biomass of the world's forests. Annu Rev Ecol Evol Syst. 2013;44:593-622. This paper reviews the environmental controls on the spatial distribution of forests worldwide.

3. Brown S, Lugo AE. Tropical secondary forests. J Trop Ecol. 1990;6(01):1-32.

4. Brienen R, Phillips O, Feldpausch T, Gloor E, Baker T, Lloyd J, et al. Long-term decline of the Amazon carbon sink. Nature. 2015;519(7543):344-8.

5. UNEP, FAO, UNFF. Vital forest graphics. 2009.

6. Billington $\mathrm{C}$, Kapos $\mathrm{V}$, Edwards $\mathrm{M}$, Blyth $\mathrm{S}$, Iremonger $\mathrm{S}$. Estimated original forest cover map - a first attempt. World Conservation Monitoring Centre (http://www.unep-wcmc.org/ forest/original.htm). 1996.

7. Herold M, Román-Cuesta RM, Mollicone D, Hirata Y, Van Laake $\mathrm{P}$, Asner GP, et al. Options for monitoring and estimating historical carbon emissions from forest degradation in the context of REDD+. Carbon Balance Manage. 2011;6(13):1-7.

8. Saatchi S, Mascaro J, Xu L, Keller M, Yang Y, Duffy P et al. Seeing the forest beyond the trees. Glob Ecol Biogeogr. 2014;24 (5):606-10.

9. Olson DM, Dinerstein E, Wikramanayake ED, Burgess ND, Powell GV, Underwood EC, et al. Terrestrial ecoregions of the world: a new map of life on earth a new global map of terrestrial ecoregions provides an innovative tool for conserving biodiversity. Bioscience. 2001;51(11):933-8.

10. Udvardy MD, Udvardy M. A classification of the biogeographical provinces of the world. Switzerland: International Union for Conservation of Nature and Natural Resources Morges; 1975.

11. Pielou EC. Biogeography. New York: Wiley; 1979. p. 351.

12.• Hansen M, DeFries R, Townshend J, Carroll M, Dimiceli C, Sohlberg R. Global percent tree cover at a spatial resolution of 500 meters: first results of the MODIS vegetation continuous fields algorithm. Earth Interact. 2003;7(10):1-15. This paper presents one of the finer-scale depictions of global tree cover.

13. Lefsky MA. A global forest canopy height map from the moderate resolution imaging spectroradiometer and the geoscience laser altimeter system. Geophys Res Lett. 2010;37(15):L15401. doi:10. 1029/2010GL043622.

14. Simard M, Pinto N, Fisher JB, Baccini A. Mapping forest canopy height globally with spaceborne lidar. J Geophys Res Biogeosci. 2011;116(G4):n/a-n/a. doi:10.1029/2011JG001708.

15. Fujimori T. Ecological and silvicultural strategies for sustainable forest management. Elsevier; 2001. p. 412.
16. Duke NC. Mangrove floristics and biogeography. In: Robertson AI, Alongi DM, editors. Tropical mangrove ecosystems. Washington D.C: American Geophysical Union; 1993.

17. Thurner M, Beer C, Santoro M, Carvalhais N, Wutzler T, Schepaschenko D, et al. Carbon stock and density of northern boreal and temperate forests. Glob Ecol Biogeogr. 2014;23(3): 297-310. This paper provides a benchmark map of forest carbon stocks across the temperate and boreal forest ecoregion.

18. Yamada I. Tropical rain forests of Southeast Asia: a forest ecologist's view. Honolulu: University of Hawaii Press; 1997.

19. Moore PD. Tropical forests. Facts On file, Incorporated; 2009.

20. Santini NS, Reef R, Lockington DA, Lovelock CE. The use of fresh and saline water sources by the mangrove Avicennia marina. Hydrobiologia. 2015;745(1):59-68.

21. Saatchi SS, Harris NL, Brown S, Lefsky M, Mitchard ET, Salas W, et al. Benchmark map of forest carbon stocks in tropical regions across three continents. Proc Natl Acad Sci. 2011;108(24):9899_ 904. This paper provides a benchmark map of forest carbon stocks across the pan-tropics.

22. Baccini A, Goetz S, Walker W, Laporte N, Sun M, Sulla-Menashe $\mathrm{D}$, et al. Estimated carbon dioxide emissions from tropical deforestation improved by carbon-density maps. Nat Clim Chang. 2012;2(3):182-5.

23. Mitchard ET, Saatchi SS, Baccini A, Asner GP, Goetz SJ, Harris $\mathrm{NL}$, et al. Uncertainty in the spatial distribution of tropical forest biomass: a comparison of pan-tropical maps. Carbon Balance Manage. 2013;8(10):1-13.

24. Quiñones M, Hoekman D, Schut V, Wielaard N. Above ground biomass map of Kalimantan. SarVision Report \# 80087. 2011.

25. Mitchard ET, Saatchi SS, White L, Abernethy K, Jeffery KJ, Lewis SL, et al. Mapping tropical forest biomass with radar and spaceborne LiDAR in Lopé National Park, Gabon: overcoming problems of high biomass and persistent cloud. Biogeosciences. 2012;9:179-91.

26. Asner GP, Mascaro J, Anderson C, Knapp DE, Martin RE, Kennedy-Bowdoin $\mathrm{T}$ et al. High-fidelity national carbon mapping for resource management and REDD+. Carbon balance and, management. 2013;8(7).

27. Gautam B, Peuhkurinen J, Kauranne T, Gunia K, Tegel K, LatvaKäyrä P et al.. Estimation of forest carbon using LiDAR-assisted multi-source programme (LAMP) in Nepal. Proceedings of the International Conference on Advanced Geospatial Technologies for Sustainable Environment and Culture, Pokhara, Nepal (an event of ISPRS Technical Commission VI, Education and Outreach, Working Group 6) (http://www.researchgate.net/ publication/258514247_Estimation_of_forest_carbon_using LiDARassisted_multi-source program_(LAMP)_in_Nepal). 2013.

28. Englhart S, Keuck V, Siegert F. Aboveground biomass retrieval in tropical forests - the potential of combined X-and L-band SAR data use. Remote Sens Environ. 2011;115(5):1260-71.

29. Williams ML, Milne T, Tapley I, Reis J, Sanford M, Kofman B et al., editors. Tropical forest biomass recovery using GeoSAR observations. Geoscience and Remote Sensing Symposium, 2009 I.E. International, IGARSS 2009; 2009: IEEE.

30. Anaya JA, Chuvieco E, Palacios-Orueta A. Aboveground biomass assessment in Colombia: a remote sensing approach. For Ecol Manage. 2009;257(4):1237-46.

31. Cartus O, Kellndorfer J, Walker W, Franco C, Bishop J, Santos L, et al. A national, detailed map of forest aboveground carbon stocks in Mexico. Remote Sens. 2014;6(6):5559-88.

32. Hernández-Stefanoni JL, Dupuy JM, Johnson KD, Birdsey R, Tun-Dzul F, Peduzzi A, et al. Improving species diversity and biomass estimates of tropical dry forests using airborne LiDAR. Remote Sens. 2014;6(6):4741-63. 
33. Nizalapur V, Jha CS, Madugundu R. Estimation of above ground biomass in Indian tropical forested area using multifrequency DLRESAR data. Int J Geom Geoscie. 2010;1(2):167-78.

34. Avtar R, Suzuki R, Takeuchi W, Sawada H. PALSAR 50 m mosaic data based national level biomass estimation in Cambodia for implementation of REDD+ mechanism. PLoS One. 2013;8(10): e74807.

35. Padron E, Navarro-Cerrillo RM. Aboveground biomass in Prosopis pallida (Humb and Bonpl Ex Willd) HBK ecosystems using Landsat 7 ETM+ images. Revista Chilena de Historia Natural, Santiago del Chile. 2007;80:43-53.

36. Giri C, Ochieng E, Tieszen L, Zhu Z, Singh A, Loveland T, et al. Status and distribution of mangrove forests of the world using earth observation satellite data. Glob Ecol Biogeogr. 2011;20(1): 154-9.

37. Simard M, Fatoyinbo LE, Pinto N. Mangrove canopy 3D structure and ecosystem productivity using active remote sensing. Chapter 3. In: Wang Y, editor. Remote sensing of coastal environments. CRC Press; 2009. p. 61-78. doi:10.1201/9781420094428-c3.

38. Simard M, Zhang K, Rivera-Monroy VH, Ross MS, Ruiz PL, Castañeda-Moya E, et al. Mapping height and biomass of mangrove forests in Everglades National Park with SRTM elevation data. Photogramm Eng Remote Sens. 2006;72(3):299-311.

39. Simard M, Rivera-Monroy VH, Mancera-Pineda JE, CastañedaMoya E, Twilley RR. A systematic method for 3D mapping of mangrove forests based on shuttle radar topography mission elevation data, ICEsat/GLAS waveforms and field data: application to Ciénaga Grande de Santa Marta, Colombia. Remote Sens Environ. 2008;112(5):2131-44. doi:10.1016/j.rse.2007.10.012.

40. Fatoyinbo TE, Simard M, Washington-Allen RA, Shugart HH. Landscape-scale extent, height, biomass, and carbon estimation of Mozambique's mangrove forests with Landsat ETM+ and Shuttle Radar Topography Mission elevation data. Journal of Geophysical Research. 2008;113(G02S06). doi:10.1029/ 2007JG000551.

41. Lucas R, Rebelo L-M, Fatoyinbo L, Rosenqvist A, Itoh T, Shimada $\mathrm{M}$, et al. Contribution of L-band SAR to systematic global mangrove monitoring. Mar Freshw Res. 2014;65(7):589-603.

42. Fatoyinbo TE, Simard M. Height and biomass of mangroves in Africa from ICESat/GLAS and SRTM. Int J Remote Sens. 2013;34(2):668-81.

43. Hutchison J, Manica A, Swetnam R, Balmford A, Spalding M. Predicting global patterns in mangrove forest biomass. Conserv Lett. 2014;7(3):233-40.

44. Sankaran M, Ratnam J. African and Asian Savannas. Encyclopedia of Biodiversity, 2nd edition, Levin, S (Ed). 2013;1:58-74.

45. Mermoz S, Le Toan T, Villard L, Réjou-Méchain M, SeifertGranzin J. Biomass assessment in the Cameroon savanna using ALOS PALSAR data. Remote Sens Environ. 2014;155:109-19.

46. Lucas R, Armston J, Fairfax R, Fensham R, Accad A, Carreiras J, et al. An evaluation of the ALOS PALSAR L-band backscatterabove ground biomass relationship Queensland, Australia: impacts of surface moisture condition and vegetation structure. IEEE J Sel Top Appl Earth Obs Remote Sens. 2010;3(4):57693. This paper explores the impact of surface moisture on retrieval of above ground biomass using L-band SAR.

47. Lucas R, Scarth P, Armston J, Gill T, Phinn S, Clewley D et al. Australia's National Biomass Mapping Project — updates from the UQ JRSRP and JAXA K\&C Initiative. Presentation at the Joint Expert Workshop on Approaches to Remote Sensing for Vegetation Biomass Estimation, Brisbane, Australia, 24-26 Feb. 2015.

48. Michelakis D, Stuart N, Lopez G, Linares V, Woodhouse IH. Local-scale mapping of biomass in tropical lowland pine savannas using ALOS PALSAR. Forests. 2014;5(9):2377-99.
49. Mitchard ETA, Saatchi SS, Lewis SL, Feldpausch TR, Woodhouse $\mathrm{IH}$, Sonké B, et al. Measuring biomass change due to woody encroachment and deforestation/degradation in a forest-savanna boundary region of central Africa using multi-temporal L-band radar backscatter. Remote Sens Environ. 2011;115:2861-73.

50. Cirrus Group Synopsis Report: South African carbon sink assessment. Evidence on Demand. 2014:42. doi:http://dx.doi.org/10. 12774/eod_cr.september2014.cirrusgroup.

51. Kurtz DB, Schellberg J, Braun M. Ground and satellite based assessment of rangeland management in sub-tropical Argentina. Appl Geogr. 2010;30(2):210-20.

52. Vayreda J, Gracia M, Canadell JG, Retana J. Spatial patterns and predictors of forest carbon stocks in western Mediterranean. Ecosystems. 2012;15(8):1258-70.

53. García-Martín A, Pérez-Cabello F, de la Riva J, Montorio R. Using remote sensing to estimate a renewable resource: forest residual biomass. INTECH Open Access Publisher; 2012.

54. Calvao T, Palmeirim J. Mapping Mediterranean scrub with satellite imagery: biomass estimation and spectral behaviour. Int J Remote Sens. 2004;25(16):3113-26.

55. Santi E, Tarantino C, Amici V, Bacaro G, Blonda P, Borselli L, et al. Fine scale spatial distribution of biomass using satellite images. J Ecol Nat Environ. 2014;6:75-86.

56. García M, Riaño D, Chuvieco E, Danson FM. Estimating biomass carbon stocks for a Mediterranean forest in central Spain using LiDAR height and intensity data. Remote Sens Environ. 2010;114(4):816-30.

57. Svoray T, Shoshany M. The synergy of optical data with microwave backscattering model for the retrieval of soil and vegetation conditions in heterogeneous Mediterranean environment. Int Arch Photogramm Remote Sens. 2000;33(B1; Part 1):322-7.

58. Cartus O, Santoro M, Kellndorfer J. Mapping forest aboveground biomass in the Northeastern United States with ALOS PALSAR dual-polarization L-band. Remote Sens Environ. 2012;124:466-78.

59. Tsui OW, Coops NC, Wulder MA, Marshall PL, McCardle A. Using multi-frequency radar and discrete-return LiDAR measurements to estimate above-ground biomass and biomass components in a coastal temperate forest. ISPRS J Photogramm Remote Sens. 2012;69:121-33.

60. Hyde P, Dubayah R, Walker W, Blair JB, Hofton M, Hunsaker C. Mapping forest structure for wildlife habitat analysis using multisensor (LiDAR, SAR/InSAR, ETM+, Quickbird) synergy. Remote Sens Environ. 2006;102(1):63-73.

61. Nelson RF, Hyde P, Johnson P, Emessiene B, Imhoff ML, Campbell R, et al. Investigating RaDAR-LiDAR synergy in a North Carolina pine forest. Remote Sens Environ. 2007;110(1): 98-108.

62. Blackard J, Finco M, Helmer E, Holden G, Hoppus M, Jacobs D, et al. Mapping US forest biomass using nationwide forest inventory data and moderate resolution information. Remote Sens Environ. 2008;112(4):1658-77.

63. Du L, Zhou T, Zou Z, Zhao X, Huang K, Wu H. Mapping forest biomass using remote sensing and national forest inventory in China. Forests. 2014;5(6):1267-83.

64. Dong J, Kaufmann RK, Myneni RB, Tucker CJ, Kauppi PE, Liski $\mathrm{J}$, et al. Remote sensing estimates of boreal and temperate forest woody biomass: carbon pools, sources, and sinks. Remote Sens Environ. 2003;84(3):393-410.

65. Houghton R, Butman D, Bunn AG, Krankina O, Schlesinger P, Stone T. Mapping Russian forest biomass with data from satellites and forest inventories. Environ Res Lett. 2007;2(4):045032.

66. Ranson KJ, Sun G, Lang RH, Chauhan NS, Cacciola RJ, Kilic O. Mapping of boreal forest biomass from spaceborne synthetic aperture radar. J Geophys Res Atmos (1984-2012). 1997;102(D24): 29599-610. 
67. Wagner W, Luckman A, Vietmeier J, Tansey K, Balzter H, Schmullius C, et al. Large-scale mapping of boreal forest in SIBERIA using ERS tandem coherence and JERS backscatter data. Remote Sens Environ. 2003;85(2):125-44.

68. Neumann M, Saatchi SS, Ulander LM, Fransson JE. Assessing performance of L-and P-band polarimetric interferometric SAR data in estimating boreal forest above-ground biomass. IEEE Trans Geosci Remote Sens. 2012;50(3):714-26.

69. Santoro M, Beer C, Cartus O, Schmullius C, Shvidenko A, McCallum I, et al. Retrieval of growing stock volume in boreal forest using hyper-temporal series of Envisat ASAR ScanSAR backscatter measurements. Remote Sens Environ. 2011;115(2): 490-507. This paper details the BIOMASAR algorithm for retrieval of forest GSV using hypertemporal C-band SAR.

70. Santoro M, Cartus O, Fransson JE, Shvidenko A, McCallum I, Hall $\mathrm{RJ}$, et al. Estimates of forest growing stock volume for Sweden, Central Siberia, and Québec using Envisat Advanced Synthetic Aperture Radar backscatter data. Remote Sens. 2013;5(9):4503-32.

71. Kankare V, Vastaranta M, Holopainen M, Räty M, Yu X, Hyyppä J, et al. Retrieval of forest aboveground biomass and stem volume with airborne scanning LiDAR. Remote Sens. 2013;5(5):2257-74.

72. Lehtonen A, Mäkipää R, Heikkinen J, Sievänen R, Liski J. Biomass expansion factors (BEFs) for Scots pine, Norway spruce and birch according to stand age for boreal forests. For Ecol Manage. 2004;188(1):211-24.

73. Kaasalainen S, Holopainen M, Karjalainen M, Vastaranta M, Kankare V, Karila K, et al. Combining lidar and synthetic aperture radar data to estimate forest biomass: status and prospects. Forests. 2015;6(1):252-70.

74. Walker WS, Kellndorfer JM, Pierce LE. Quality assessment of SRTM C-and X-band interferometric data: implications for the retrieval of vegetation canopy height. Remote Sens Environ. 2007;106(4):428-48.

75. Kellndorfer J, Walker W, LaPoint E, Bishop J, Cormier T, Fiske G. NACP aboveground biomass and carbon baseline data (NBCD 2000), USA. Oak Ridge: ORNL DAAC; 2012.

76. Andersen H-E, Barrett T, Winterberger K, Strunk J, Temesgen H, editors. Estimating forest biomass on the western lowlands of the Kenai Peninsula of Alaska using airborne lidar and field plot data in a model-assisted sampling design. Proceedings of the IUFRO Division 4 Conference:"Extending Forest Inventory and Monitoring over Space and Time; 2009.

77. Næsset E, Bollandsås OM, Gobakken T, Gregoire TG, Ståhl G. Model-assisted estimation of change in forest biomass over an 11year period in a sample survey supported by airborne LiDAR: a case study with post-stratification to provide "activity data". Remote Sens Environ. 2013;128:299-314. This paper presents a good example of forest biomass change mapping using repeat LiDAR.

78. Vastaranta M, Holopainen M, Karjalainen M, Kankare V, Hyyppa J, Kaasalainen S. TerraSAR-X stereo radargrammetry and airborne scanning LiDAR height metrics in imputation of forest aboveground biomass and stem volume. IEEE Trans Geosci Remote Sens. 2014;52(2):1197-204.

79. Nyström M, Holmgren J, Olsson H. Prediction of tree biomass in the forest-tundra ecotone using airborne laser scanning. Remote Sens Environ. 2012;123:271-9.

80. Solberg S, Astrup R, Breidenbach J, Nilsen B, Weydahl D. Monitoring spruce volume and biomass with InSAR data from TanDEM-X. Remote Sens Environ. 2013;139:60-7.

81. Montesano P, Cook B, Sun G, Simard M, Nelson R, Ranson K, et al. Achieving accuracy requirements for forest biomass mapping: a spaceborne data fusion method for estimating forest biomass and LiDAR sampling error. Remote Sens Environ. 2013;130:153-70.

82. Sun G, Ranson KJ, Guo Z, Zhang Z, Montesano P, Kimes D. Forest biomass mapping from lidar and radar synergies. Remote Sens Environ. 2011;115(11):2906-16.
83. Kindermann GE, McCallum I, Fritz S, Obersteiner M. A global forest growing stock, biomass and carbon map based on FAO statistics. Silva Fenn. 2008;42(3):387.

84. Ruesch A, Gibbs HK. New IPCC Tier-1 global biomass carbon map for the year 2000. Available online from the Carbon Dioxide Information Analysis Center [http://cdiac.ornl.gov/], Oak Ridge National Laboratory, Oak Ridge, Tennessee, USA. 2008.

85. IPCC. 2006 IPCC Guidelines for national greenhouse gas inventories. 2006.

86. Barredo JI, San-Miguel-Ayanz J, Caudullo G, Busetto L. A European map of living forest biomass and carbon stock. Reference Report by the Joint Research Centre of the European Commission EUR-Scientific and Technical Research. 2012;25730.

87. Liu YY, van Dijk AI, de Jeu RA, Canadell JG, McCabe MF, Evans JP, et al. Recent reversal in loss of global terrestrial biomass. Nat Clim Chang. 2015;5:470-4.

88. Ghasemi N, Sahebi MR, Mohammadzadeh A. A review on biomass estimation methods using synthetic aperture radar data. Int $\mathrm{J}$ Geom Geosci. 2011;1(4):776-88.

89. Lu D, Chen Q, Wang G, Moran E, Batistella M, Zhang M et al. Aboveground forest biomass estimation with Landsat and LiDAR data and uncertainty analysis of the estimates. Int J For Res. 2012;2012.

90. Lu D, Chen Q, Wang G, Liu L, Li G, Moran E. A survey of remote sensing-based aboveground biomass estimation methods in forest ecosystems. Int J Digital Earth. 2014(ahead-of-print):1-43.

91. Hopkinson C, Chasmer L, Kljun N, van Gorsel E, McCaughey H, Barr A et al. ALS monitoring of changes in forest biomass carbon storage. Proceedings of SilviLaser, Vancouver, Canada. 2012.

92. Hudak AT, Strand EK, Vierling LA, Byrne JC, Eitel JU, Martinuzzi S, et al. Quantifying aboveground forest carbon pools and fluxes from repeat LiDAR surveys. Remote Sens Environ. 2012;123:25-40.

93. Balzter H, Skinner L, Luckman A, Brooke R. Estimation of tree growth in a conifer plantation over 19 years from multi-satellite Lband SAR. Remote Sens Environ. 2003;84(2):184-91.

94. Ryan CM, Hill T, Woollen E, Ghee C, Mitchard E, Cassells G, et al. Quantifying small-scale deforestation and forest degradation in African woodlands using radar imagery. Glob Chang Biol. 2012;18(1):243-57.

95. Liu YY, Dijk AI, McCabe MF, Evans JP, Jeu RA. Global vegetation biomass change (1988-2008) and attribution to environmental and human drivers. Glob Ecol Biogeogr. 2013;22(6):692-705.

96. FAO. Global forest resources assessment 2005: progress towards sustainable forest management'. FAO Forestry Paper. 2006(147).

97. FAO. Global forest resources assessment 2010: Main report. Food and Agriculture Organization of the United Nations; 2010.

98. Le Toan T, Quegan S, Davidson M, Balzter H, Paillou P, Papathanassiou K, et al. The BIOMASS mission: Mapping global forest biomass to better understand the terrestrial carbon cycle. Remote Sens Environ. 2011;115(11):2850-60.

99. Asai K, Sato R, Kobayashi T, Imai T. Multi-footprint Observation LiDAR and Imager (MOLI) on the ISS-JEM Mission. Geoscience and Remote Sensing Symposium, 2014 I.E. International, IGARS S 2014.

100. Dolan K, Masek JG, Huang C, Sun G. Regional forest growth rates measured by combining ICESat GLAS and Landsat data. J Geophys Res. 2009;114:G2.

101. Calders K, Newnham G, Burt A, Murphy S, Raumonen P, Herold $\mathrm{M}$, et al. Non-destructive estimates of above-ground biomass using terrestrial laser scanning. Methods Ecol Evol. 2015;6(2): 198-208.

102. Mithal V, Garg A, Boriah S, Steinbach M, Kumar V, Potter C, et al. Monitoring global forest cover using data mining. ACM Trans Intell Syst Technol (TIST). 2011;2(4):36. 